www.mdpi.com/journal/applsci

Review

\title{
A Review of the Role of Amphiphiles in Biomass to Ethanol Conversion
}

Anahita Dehkhoda Eckard ${ }^{1, *}$, Kasiviswanathan Muthukumarappan ${ }^{1}$ and William Gibbons ${ }^{2}$

1 Department of Agricultural and Biosystems Engineering, South Dakota State University, 1400 North Campus Drive, Brookings, SD 57007, USA; E-Mail: kas.muthukum@sdstate.edu

2 Department of Biology \& Microbiology, South Dakota State University, 1400 North Campus Drive, Brookings, SD 57007, USA; E-Mail: william.gibbons@sdstate.edu

* Author to whom correspondence should be addressed; E-Mail: Anahita.Eckard@gmail.com; Tel.: +1-919-627-2334; Fax: +1-605-688-6764.

Received: 31 December 2012; in revised form: 18 February 2013 / Accepted: 25 February 2013 / Published: 2 April 2013

Abstract: One of the concerns for economical production of ethanol from biomass is the large volume and high cost of the cellulolytic enzymes used to convert biomass into fermentable sugars. The presence of acetyl groups in hemicellulose and lignin in plant cell walls reduces accessibility of biomass to the enzymes and makes conversion a slow process. In addition to low enzyme accessibility, a rapid deactivation of cellulases during biomass hydrolysis can be another factor contributing to the low sugar recovery. As of now, the economical reduction in lignin content of the biomass is considered a bottleneck, and raises issues for several reasons. The presence of lignin in biomass reduces the swelling of cellulose fibrils and accessibility of enzyme to carbohydrate polymers. It also causes an irreversible adsorption of the cellulolytic enzymes that prevents effective enzyme activity and recycling. Amphiphiles, such as surfactants and proteins have been found to improve enzyme activity by several mechanisms of action that are not yet fully understood. Reduction in irreversible adsorption of enzyme to non-specific sites, reduction in viscosity of liquid and surface tension and consequently reduced contact of enzyme with air-liquid interface, and modifications in biomass chemical structure are some of the benefits derived from surface active molecules. Application of some of these amphiphiles could potentially reduce the capital and operating costs of bioethanol production by reducing fermentation time and the amount of enzyme used for saccharification of biomass. In this review article, the benefit of applying amphiphiles at various stages of ethanol production (i.e., 
pretreatment, hydrolysis and hydrolysis-fermentation) is reviewed and the proposed mechanisms of actions are described.

Keywords: lignocellulosic biomass; cellulase; enzymatic hydrolysis; pretreatment; surfactants

\section{Introduction}

One of the foremost concerns for economically efficient ethanol production from biomass through the biochemical pathway is the high price and usage rates of cellulolytic enzymes. Several factors have substantial negative impacts on the enzymatic hydrolysis of biomass, such as lignin, acetyl groups and crystallinity of cellulose. The main negative impacts of lignin are inhibition of fiber-swelling (reducing cellulose accessibility) and enzyme deactivation through irreversible adsorption [1]. These factors reduce enzyme performance, such that higher quantities of enzyme are required to achieve acceptable hydrolysis rates and efficiencies. A typical cellulase loading of $15 \mathrm{FPU} / \mathrm{g}$ cellulose would equate to $\sim 30$ g of enzyme per liter of ethanol produced. Considering a $\$ 10 / \mathrm{kg}$ cost for cellulase, this level of enzyme accounts for $27 \%-40 \%$ of biofuel production costs [2,3], assuming a liter of ethanol is sold for $\$ 0.94$. Thus, it is essential for the enzyme cost to be reduced below $\$ 2 / \mathrm{kg}$ protein, or strategies must be developed to substantially reduce enzyme dosage rates [4-6] so that cellulolytic enzyme costs would be comparable to starch enzymes used in the corn-to-ethanol industry (\$0.02-0.03/gal ethanol). At present, a range of cost estimates for cellulolytic enzymes have been made, including \$0.10/gal [7], \$0.30/gal [8], \$0.32/gal [9], \$0.35/gal [10], \$0.40/gal [11] and \$0.68/gal [10] of ethanol produced.

A sensitivity analysis of the effects of feedstock price and fermentation residence time on the costs of enzyme production showed that at a baseline cost of \$60/MT for poplar, the enzyme costs would still be $\$ 1.30 /$ gal ethanol [10]. However, a reduction in microbial growth and fermentation period would reduce the capital costs, and thereby drop the enzyme costs. Because enzyme production costs can only be reduced so far, developing techniques to lower enzyme utilization in biomass hydrolysis is a critical aspect of reducing the production costs of ethanol from biomass [11-13]. Several approaches have been evaluated to improve enzyme performance, and hence reduce the net costs of hydrolytic enzymes. A wide range of pretreatment technologies has been developed to enable high saccharification yields at lower enzyme loadings [14,15]. Some of these pretreatments target removal of monomeric sugars [16,17], hemicellulose oligomers [18], lignin and lignin degradation products [19-21], while others may also target increased biomass porosity, or a combination of these effects. A more recent approach has been the development of techniques that maintain enzyme secondary structure and solubility, and hence activity for an extended period of time.

Amphiphiles such as emulsifiers and proteins have been found to improve the activity of a variety of enzymes by alleviating one or more of the potential enzyme inhibitors mentioned above. Examples of this beneficial effect have been reported for enzymes such as horseradish peroxidase (HRP) [22], lipoxygenase (LOX1) [23], lipase [24,25], xylanase [22], $\beta$-glucosidase and cellualse [1,26-29]. Various mechanisms of action have been described to explain these effects that will be described further in this manuscript. These emulsifiers and proteins contain simultaneously polar and non-polar regions, which impart them with surface-active properties [30] that can stabilize the two-phase system. 
Improving enzyme activity through the application of amphiphiles not only reduces the operating costs of ethanol production from biomass by reducing the amount of enzyme required, but also reduces fermentation time, thereby lowering capital costs. Therefore, due to the significant need for improved enzyme activity, and the demonstrated effective action of protein and surfactant-based enzyme stabilizers, we review the different mechanisms of action of these additives on cellulase stabilization. Enhanced catalytic activity of cellulase with surfactants has been reported for a variety of substrates, including steam exploded spruce, lodgepole pine [27,30-32], sigma cell 100 and steam exploded poplar [32], newspaper [33], Avicel and tissue paper [34], dilute sulfuric acid pretreated creeping wild ryegrass [29], Douglas fir exploded with $\mathrm{SO}_{2}$ and ammonia freeze explosion (AFEX) pretreated corn stover, dilute acid pretreated corn stover [26,35], lime and ammonia recycled percolation (ARP) pretreated corn stover [26], extrusion pretreated corn stover and prairie cord grass [36,37].

While all amphiphiles share, to some extent, common properties, "biopolymers" are favored over synthetic polymers, because the former are naturally produced, biodegradable, available at relatively low cost and do not require harsh chemical treatments to initiate polymerization. Although polyethylene glycol (PEG) or surfactants such as Tween 20 or 80 are generally recognized to be safe and stimulatory to microbes for enhanced enzyme (e.g., a-amylase) production [38] and ethanol production [39], in some cases even small quantities $(1 \mathrm{~g} / \mathrm{L})$ of Tween 20 were found to be inhibitory to Dekkera clausenii [40]. In addition, the high viscosity of surfactants and their foaming property might not be favorable attributes for scale up.

As an alternative, protein-based lignin-blockers such as soybean meal, corn steep liquor, bovine serum albumin (BSA), amylase, chicken egg albumin, and combinations thereof [41], as well as casein [37] have been evaluated during enzymatic saccharification of high lignin containing biomass. Pretreatment techniques such as ammonia fiber explosion (AFEX), dilute acid (with Parr reactor), lime, washed $\mathrm{SO}_{2}$ and Ammonia recycled percolation (ARP) pretreated corn stover, Douglas fir pretreated with $\mathrm{SO}_{2}$ explosion and Avicel were used with prior treatment with bovine serum albumin (BSA) [1,41]. Table 1 summarizes amphiphiles, pretreatment techniques, and levels of enzyme loading that have been investigated to increase activity of cellulolytic enzymes in biomass-to-ethanol processes.

Table 1. Comparison of the effectiveness of different amphiphiles for improvement of enzymatic hydrolysis of dilute acid, lime, alkali, extrusion, AFEX pretreated substrates.

\begin{tabular}{lcccccc}
\hline Pretreatment & Substrate & $\begin{array}{c}\text { Additive } \\
\text { amount } \\
\text { (g/g glucan) }\end{array}$ & Additive & $\begin{array}{c}\text { Cellulase } \\
\text { dose (FPU/g } \\
\text { glucan) }\end{array}$ & $\begin{array}{c}\text { Increase in } \\
\boldsymbol{Y}_{\mathbf{g}}(\boldsymbol{\%})\end{array}$ & References \\
\hline N/A & Avicel & 0.30 & PEG 6000 & 8.6 & 3.0 & Eckard et al. [36] \\
& Avicel & 0.60 & Tween 20 & 7.5 & 64.0 & Kumar and Wyman [26] \\
& Avicel & 0.30 & Tween 20 & 8.6 & 12.0 & Eckard et al. [37] \\
& Avicel & 0.06 & PEG 4000 & 15.0 & 51.0 & Errikson et al. [27] \\
& Avicel & 0.50 & Casein & 15.0 & 0.0 & Eckard et al. [42] \\
\hline \multirow{2}{*}{ N/A } & Newspaper & 0.60 & Tween 20 & $2.0 *$ & 55.0 & Wu and Ju [40] \\
& Newspaper & 0.60 & Tween 80 & $2.0 *$ & 42.9 & Wu and Ju [40] \\
& Newspaper & 0.60 & F 68 & $2.0 *$ & 64.2 & Wu and Ju [40] \\
& Newspaper & 0.60 & F 88 & $2.0 *$ & 63.7 & Wu and Ju [40] \\
\hline
\end{tabular}


Table 1. Cont.

\begin{tabular}{|c|c|c|c|c|c|c|}
\hline Pretreatment & Substrate & $\begin{array}{c}\text { Additive } \\
\text { amount } \\
\text { (g/g glucan) } \\
\end{array}$ & Additive & $\begin{array}{c}\text { Cellulase dose } \\
\text { (FPU/g } \\
\text { glucan) }\end{array}$ & $\begin{array}{c}\text { Increase in } \\
Y_{\mathrm{g}}(\%)\end{array}$ & References \\
\hline \multirow[t]{5}{*}{ AFEX } & Corn stover & 0.60 & BSA & 7.5 & 11.6 & Kumar and Wyman [26] \\
\hline & Corn stover & 0.60 & Tween 20 & 7.5 & 10.3 & Kumar and Wyman [26] \\
\hline & Corn stover & 0.60 & PEG 6000 & 7.5 & 6.5 & Kumar and Wyman [26] \\
\hline & Corn stover & 0.50 & Casein & 25.0 & 17.4 & Eckard et al. [42] \\
\hline & Corn stover & 2.50 & Casein & 25.0 & 23.7 & Eckard et al. [42] \\
\hline \multirow[t]{7}{*}{ Dilute acid } & Corn stover & 0.60 & BSA & 3.0 & 26.3 & Kumar and Wyman [26] \\
\hline & Corn stover & 1.40 & BSA & 15.0 & 12.1 & Yang and Wyman [35] \\
\hline & Corn stover & 1.40 & BSA & 7.5 & 12.1 & Yang and Wyman [35] \\
\hline & Corn stover & 0.60 & Tween 20 & 3.0 & 36.0 & Kumar and Wyman [26] \\
\hline & Corn stover & 0.60 & PEG & 3.0 & 45.8 & Kumar and Wyman [26] \\
\hline & Corn stover & 0.50 & Casein & 25.0 & 31.9 & Eckard et al. [42] \\
\hline & Corn stover & 2.50 & Casein & 25.0 & 31.0 & Eckard et al. [42] \\
\hline \multirow[t]{5}{*}{ Lime } & Corn stover & 0.60 & Tween 20 & 7.5 & 20.0 & Kumar and Wyman [26] \\
\hline & Corn stover & 0.60 & BSA & 7.5 & 3.0 & Kumar and Wyman [26] \\
\hline & Corn stover & 0.60 & PEG & 7.5 & 0.0 & Kumar and Wyman [26] \\
\hline & Corn stover & 0.50 & Casein & 25.0 & 17.0 & Eckard et al. [42] \\
\hline & Corn stover & 2.50 & Casein & 25.0 & 22.3 & Eckard et al. [42] \\
\hline \multirow[t]{5}{*}{ Alkali } & Corn stover & 0.15 & Triton X-100 & 15.0 & 0.0 & Eckard et al. [43] \\
\hline & Corn stover & 0.30 & Brij 30 & 15.0 & 0.0 & Eckard et al. [43] \\
\hline & Corn stover & 0.47 & Tween 20 & 15.0 & 0.0 & Eckard et al. [43] \\
\hline & Corn stover & 0.50 & Casein & 25.0 & 22.7 & Eckard et al. [42] \\
\hline & Corn stover & 2.50 & Casein & 25.0 & 24.8 & Eckard et al. [42] \\
\hline \multirow[t]{4}{*}{ Extrusion } & Corn stover & 0.47 & Tween 20 & 8.6 & 27.5 & Eckard et al. [37] \\
\hline & Corn stover & 0.51 & PEG 6000 & 8.6 & 25.4 & Eckard et al. [36] \\
\hline & Corn stover & 0.50 & Casein & 25.0 & 29.5 & Eckard et al. [42] \\
\hline & Corn stover & 2.50 & Casein & 25.0 & 38.4 & Eckard et al. [42] \\
\hline \multirow[t]{5}{*}{ Raw } & Corn stover & 0.15 & BSA & 7.5 & 22.5 & Kumar and Wyman [26] \\
\hline & Corn stover & 0.30 & Tween 20 & 7.5 & 16.7 & Kumar and Wyman [26] \\
\hline & Corn stover & 0.15 & PEG & 7.5 & 22.2 & Kumar and Wyman [26] \\
\hline & Corn stover & 0.50 & Casein & 25.0 & 14.4 & Eckard et al. [42] \\
\hline & Corn stover & 2.50 & Casein & 25.0 & 23.5 & Eckard et al. [42] \\
\hline
\end{tabular}

* An enzyme level of $2.0 \mathrm{~g} / \mathrm{L}$ was used in research conducted by $\mathrm{Wu}$ and Ju. [40].

\subsection{Impact of Amphiphiles on Hydrolysis and Fermentation of Biomass}

Studies that applied surfactants or protein-based amphiphiles during enzymatic hydrolysis of lignocellulosic biomass with cellulase and/or xylanase, reported that surfactants can increase sugar yield from lignocellulosic substrates [1,19,26,27,37,38,44,45]. In a typical procedure, pretreated biomass is incubated with nonionic surfactants $(0.15$ to $0.75 \mathrm{~g} / \mathrm{g}$ glucan $)[26,37,38]$ in a shaking incubator at temperatures of $50-60{ }^{\circ} \mathrm{C}$ for $1 \mathrm{~h}$ [44], or $15 \mathrm{~min}-4 \mathrm{~h}[1,26,36]$ prior to addition of cellulase. This procedure has resulted in a range of sugar yield improvements shown in Table 1. Some authors have tested the impact of amphiphiles on separate or simultaneous saccharification and 
fermentation of biomass (SHF and SSF). Alkasrawi et al. [39] reported several positive effects from the application of Tween $20(2.5 \mathrm{~g} / \mathrm{L})$ during SSF of softwood. These benefits included enhanced liquefaction and a $50 \%$ reduction in enzyme use, an $8 \%$ increase in ethanol yield, and reduced fermentation time. In agreement with these results, Ballstros et al. [38] demonstrated that Tween 80 $(0.4 \mathrm{~g} / \mathrm{L})$ and Zeolite-like products $(2.5 \mathrm{~g} / \mathrm{L})$ increased ethanol yield significantly during SSF of steam-exploded poplar. Other studies also demonstrated a similar positive effect of surfactants such as Tween 80 , rhamnolipid, and surfactin on microbial fermentation processes for xylanase and $\alpha$-amylase production, respectively [38]. Likewise, Tween 80 was shown to significantly improve ethanol yield following SSF and SHF of steam exploded lodgepole pine (SELP) substrate by preventing the inhibiting role of the nonproductive sites of the biomass [31,46]. Moreover, the application of $0.7 \mathrm{~g} / \mathrm{L}$ of Tween during a SSF process increased lactic acid production by $24 \%$ after $72 \mathrm{~h}$. Contrary to the above studies, some investigations have shown that even small quantities of Tween 80 can be inhibitory to some yeast strains [47]. As noted previously, $1 \mathrm{~g} / \mathrm{L}$ of Tween 20 was found to be inhibitory to D. clausenii [40]. So although the surfactants such as Tween and PEG are FDA approved and generally considered harmless for living organisms, it appears that the positive or negative effect of these molecules on microbes varies depends on the microbial strain. However, a more systematic evaluation of the effects of surfactants on microbes is needed.

\subsection{Impact of Amphiphiles on Enzyme Recycling}

Due to the high cost of cellulolytic enzymes and their high dosage rates (e.g., $15 \mathrm{FPU} / \mathrm{g}$ glucan) for biomass conversion, enzyme recycling has been evaluated in several studies. One study noted an $85 \%$ reduction in enzyme activity $\left(\mathrm{Ctec}_{2}-15 \mathrm{FPU} / \mathrm{g}\right.$ glucan) after $24 \mathrm{~h}$ hydrolysis of corn stover that contained $\sim 20.2 \%$ lignin [36]. The author's hypothesized that the reason for the reduced enzyme activity was deformation and/or de-solubilization of cellulase caused by the high concentration of lignin in pretreated biomass. For enzymes to be efficiently recycled, it is important for them to remain free in solution or be washed off the biomass with sodium chloride solution to some extent [1]. The ability of amphiphiles to adhere to non-productive sites of the biomass and prevent irreversible enzyme adsorption has been clearly demonstrated before [27,33,36,48]. According to Errikson et al. [27], the adsorption of cellobiohydrolase decreased by $60 \%-70 \%$ onto steam exploded lodgepole pine (SELP) using Tween 20. Likewise, desorption of cellulases (cellobiohydrolase and endoglucanase) into the liquid phase was improved from $46 \%$ to $73 \%$ during the hydrolysis of SELP when Tween 80 was used as an enzyme stabilizer [31]. This property of amphiphiles can be exploited for recycling of cellulase if the revenue made from the additional amount of sugar and ethanol is higher than the cost paid for the amphiphiles.

For enzyme recycling, a re-adsorption technique was first proposed by Sinistyn et al. [49] as an alternative to costly ultra-filtration techniques. In this process, the slurry of hydrolysate or fermentation broth is centrifuged or filtered, and the supernatant containing soluble enzymes is incubated with fresh biomass for $2 \mathrm{~h}$ to allow the adsorption of free enzymes onto fresh biomass. Then after a second separation step, the biomass residues are re-solubilized in fresh buffer and additional $\beta$-glucosidase is added for another cycle of hydrolysis or fermentation [31,46]. It has been suggested that the re-adsorption technique prevents the accumulation of lignin degradation by-products to toxic 
levels $[31,50,51]$. Due to the advantage of the SSF process that assimilates the inhibitors and sugars as they are generated, we believe that a re-adsorption process might not be necessary considering that it adds additional costs to the process through the addition of an extra separation step, water and $\beta$-glucosidase.

When surfactant was applied to ethanol pretreated lodgepole pine (EPLP), it increased the free enzyme levels of celluclast and spezyme cp from $71 \%$ of the original amount to $96 \%$. Similarly, in another study it was found that the efficiency of enzyme recycling (using re-adsorption technique) was significantly higher in lower lignin content substrates, compared to feedstocks such as SELP that contained higher lignin levels [31]. Differences in enzyme recycling also appear to be related to the source of enzymes. For instance, under similar experimental conditions (similar substrate and surfactant), enzymes from Trichoderma ressei were successfully recycled for 4 cycles, while Penicillium-derived enzyme was only recycled once successfully [31].

According to Eckard et al. [52], after two steps recycling of fermentation liquor containing enzymes, the ethanol yield was improved by $80 \%$ and $130 \%$ with the aid of Tween and liquid casein micelles, respectively. Polymeric micelles (PMs) of PEG-Tween and PEG-Casein improved enzyme recycling further, such that the ethanol yield was improved by $50 \%$ and $108 \%$ beyond that obtained with only Tween and casein, respectively. Amphiphiles of acid casein were also found to improve the sugar recovery and fermentability of dilute acid, lime, alkali, extrusion pretreated corn stover by up to $31 \%$ and $33 \%$, respectively. Neither of Tween 20 , nor the accumulated sugars showed toxicity to microbial or enzyme activity [42].

\section{Mechanism of Action}

Several mechanism of action have been suggested to describe how surfactants enhance the cellulase activity and enzymatic hydrolysis of pure cellulose or lignocellulosic biomass: (1) surfactants can extract hydrophobic degradation products from lignin and hemicellulose by forming emulsions, thereby enhancing the removal of lignin and increasing the access of feedstock's reaction sites to the cellulolytic enzyme [31,53,54]; (2) surfactants lessen irreversible, non-productive adsorption of cellulase to non-productive sites of biomass (e.g., crystalline cellulose and lignin), which allows the enzyme to be available in solution and have higher activity [27,33,48]; (3) improved electrostatic interaction between surfactant monomer or micelles and enzyme causes an enhanced enzyme activity by activating a certain amino acid in the enzyme [55,56] or reforming enzyme secondary structure, specially the $\alpha$-helixes [43,52]; (4) surfactants protect enzyme from thermal deactivation after extended incubation period $[52,56]$ and denaturation by reducing the surface tension and viscosity of liquid that in turn diminishes the contact of enzyme with air-liquid interface [56]. Overall, in a solution of surfactants, enzymatic reactions occur either inside the surfactant micelle core or at the interface of the micelles or monomers and the pseudo-phase of the liquid, depending on the enzyme hydrophobicity [57]. In spite of the above hypotheses, a mechanism that can consistently explain how surfactants improve enzymatic hydrolysis has yet to be developed.

\subsection{Impact of Amphiphiles as Biomass Modifier}

The presence of lignin in pretreated biomass solutions is an important factor, since processes that use organic solvents to extract lignin are currently too expensive to make the cellulosic ethanol 
economically justifiable [18]. Evidence shows that lignin is released into solution during pretreatment with acid or just water/steam, and then reacts to form compounds with limited solubility. These compounds precipitate onto the surface of substrate [58,59], and the deposited lignin irreversibly adsorbs enzymes [60]. When enzymatic hydrolysis of mixtures of cellulose and lignin was conducted in the presence of tri-block-polymer of L64, cellulose was observed to settle at $50{ }^{\circ} \mathrm{C}$ in a water bath; however, lignin and L64 remained suspended in solution. An even further separation of lignin into the L64-rich phase occurred at $70{ }^{\circ} \mathrm{C}$. Other surfactants such as PEG 4000 and Triton X-100 also demonstrated similar behaviors [28].

According to Qing et al. [18], when pretreated biomass is treated with surfactants, a significant amount of the lignin released into the liquid phase could be captured by surfactant-water emulsions, thereby reducing the amount of lignin re-deposited on biomass. Kurakake et al. [22] showed that application of $3.33 \mathrm{wt} \%$ of the non-ionic surfactant of Tween 20 during pretreatment of baggase at 170-190 ${ }^{\circ} \mathrm{C}$ enhanced subsequent enzymatic hydrolysis and diminished the amount of residual lignin deposited in/on treated substrate by $22 \%-27 \%$ compared to those treated with water (control). Recently it was demonstrated that soaking corn stover in Tween 80 followed by dilute acid pretreatment $\left(140{ }^{\circ} \mathrm{C}, 1 \% \mathrm{H}_{2} \mathrm{SO}_{4}\right)$ increased lignin removal by 52\% [18]. A similar Tween 80 soaked-corn stover, hydrothermally pre-treated at $220{ }^{\circ} \mathrm{C}$, resulted in $114 \%$ increase in lignin removal [18]. Lignin removal in these samples was calculated based on actual compositional analysis of biomass with the Klason-lignin method according to NREL Laboratory Analytical Procedure \#003 (NREL, 1996). It is probable that the surfactant emulsions isolated the released lignin, and prevented its re-deposition on the surface of biomass (via hydrophobic interaction) that would non-productively adsorb or block enzyme during enzymatic hydrolysis (See Figure 1 for clarification).

Figure 1. A schematic of enzymatic hydrolysis of lignocellulosic biomass pretreated with dilute acid technique in which part of the released lignin materials are re-deposited back onto the biomass and irreversibly adsorbed the enzyme (I); Treatment of dilute acid pretreated biomass with surfactants isolated part of the lignin with monomers of surfactants. This prevents irreversible adsorption of enzymes to non-productive sites of the biomass (e.g., lignin) (II). Brown lines: lignin, grey lines: crystalline and amorphous cellulose, red dots: enzymes, blue objects: surfactants. For simplicity, hemicellulose was not shown in this image.

I

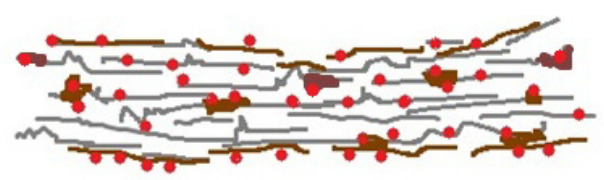

II

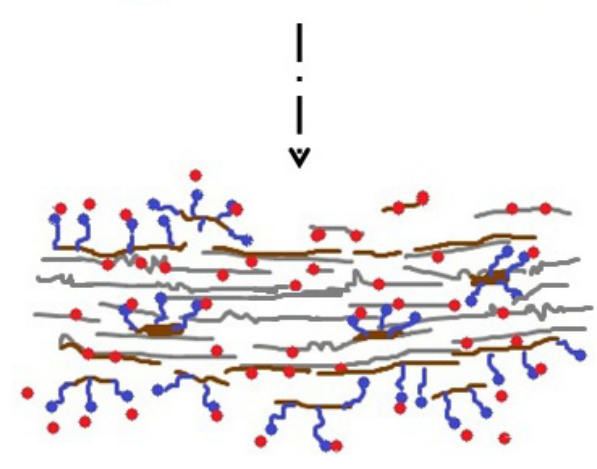


Hydrophobicity tests conducted by Qing et al. [18] showed that the biomass surface became more hydrophilic following surfactant treatment. It was postulated that this could have been due to the surfactant-assisted removal of lignin, which is hydrophobic in nature. Furthermore, Seo et al. [54] demonstrated a significant increase in water retention in biomass treated with Tween 20; similar to that of $\mathrm{NaOH}$. They hypothesized that Tween 20 can affect the swelling of lignocellulose as much as $\mathrm{NaOH}$. These results were in agreement with Kim et al. [19] who demonstrated (based on SEM analysis) that application of Tween 80 caused cellulose filter paper to swell, and enhanced surface cracks and filaments caused by native CBH I but not by core CBH I [19].

\subsection{Impact of Amphiphiles on Enzyme Desorption}

According to a proposed model (Figure 2), if polymers of PEG are used at certain concentration on the adsorbed surface, then at the time of the contact of protein of interest (e.g., enzyme) with polymer (e.g., formed mushroom regime), one of the strands of polymer would be squeezed out from the beneath the enzyme pushing the protein into solution due to increased entropy. As enzyme activity and enzyme concentration should have a direct correlation at an optimum condition of $\mathrm{pH}$, temperature and shear rate [61], an evaluation of product concentration that is also correlated with enzyme concentration can be used to evaluate enzyme activity.

Figure 2. The escape transition following protein compression of a PEG polymer that has been adsorbed to the surface in mushroom regime. (Adopted from Allen et al. [62], based on Steels et al. [63]). Uncompress (I), Compressed (II), Chain escape (III).

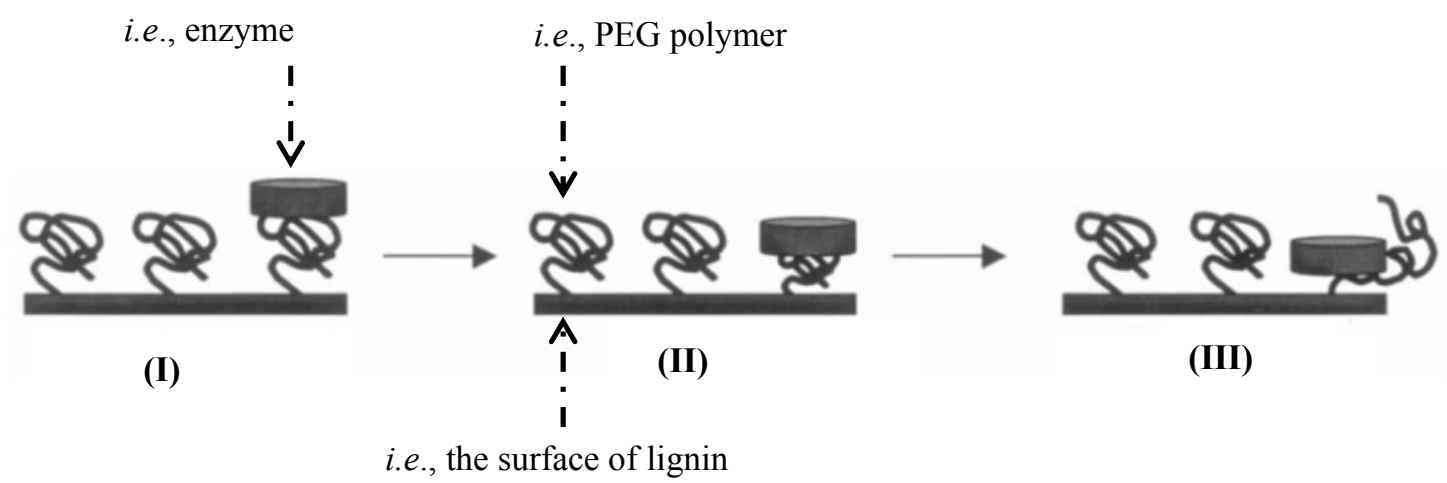

To be able to assess the enzyme concentration at a specific time point, it is helpful to first study the adsorption equilibrium of the enzyme. Li et al. [12] showed that the equilibrium time for adsorption of dialyzed commercial enzyme (Accelerase ${ }^{\mathrm{TM}} 1000$ ) to cellulosic substrate was reported to be 45 min for cellulosic biomass (with $4.2 \%$ lignin) and $60 \mathrm{~min}$ for isolated lignin. However, according to Amadeus et al. [64] the adsorption of Cel7A (CBH I) to substrate increased constantly from 30 min up to $300 \mathrm{~min}$. This author also reported that the adsorption of Cel7A to SPS was reversible after $24 \mathrm{~h}$. In addition, when adsorption of $\beta$-glucosidase was studied during the hydrolysis of PNPG, $60 \%$ of the initial enzyme activity was found on liquid phase and $40 \%$ in solid phase. The result of analysis conducted with SDS-PAGE and sugar yield showed a rapid initial adsorption of this enzyme to substrate followed by immediate desorption in the solution [64]. 
However other authors such as Chen et al. [65] and Lee et al. [66] have found that for Kraft wood and soft wood, the majority of CBHs (cellubiohydrolase) and EGs (endoglucanase) were adsorbed to lignin and were not re-solubilized in solution after the completion of cellulose hydrolysis. Typically, at the first step of the hydrolysis, cellulase adsorbs to both active and non-active sites of the biomass, and as the reaction progresses, the enzymes that were adsorbed to the active sites start being released into the solution when cellulosic carbohydrate digestion evolves [34,67].

Kim et al. [68] tested the impact of Tween 20 on adsorption of endoglucanase I (EndoI) and exoglucanase II (ExoII) using microcrystalline cellulose as the substrate. As a result it was found that in the presence of Tween 20 the adsorption of ExoI to cellulose was enhanced, while the desorption of ExoII from insoluble substrate was enhanced. According to Kim et al. [68], the increase in hydrolytic performance of cellulase by Tween 20 was attributed to both activation of ExoII and partial defibrillation of cellulose.

The analysis for the protein content of the supernatant of native $\mathrm{CBH} 1$ and core $\mathrm{CBH} 1$ of a solution containing Tween 80-treated ball milled cellulose (BMC) demonstrated reduced adsorption of both native $\mathrm{CBH} 1$ and core $\mathrm{CBH} 1$ onto BMC [19]. Furthermore, Seo et al. [53] reported that Tween 20 lowered the non-biospecific adsorption of $\beta$-glucosidase and increased the bio-specific adsorption of cellulase onto cellulose at reduced or non-hydrolytic temperature. The result of another study showed that, commercial enzyme $\left(\mathrm{Ctec}_{2}\right)$ was adsorbed on both pure cellulose and biomass, and after $24 \mathrm{~h}$ hydrolysis, $20.6 \%(1.71 \%$ out of $8.29 \% \mathrm{w} / \mathrm{w})$ and $9.5 \%(0.79 \%$ out of $8.29 \% \mathrm{w} / \mathrm{w})$ of enzymes were adsorbed to the Avicel and extruded corn stover (CS), respectively. After the addition of PEG the adsorption of enzyme was decreased by $14.0 \%$ for Avicel and by $20.2 \%$ for CS [36]. It is plausible that PEG 6000 does not retain affinity to Avicel to the same extent as biomass to be able to prevent enzyme non-productive adsorption.

According to Borjesson et al. [28], the impact of enzyme stabilizer on prohibition of enzyme from irreversible adsorption varied based on the enzyme type. For instance the adsorption of full-length enzyme and catalytic modulus of Cel7A and Cel7B to steam exploded spruce wood chips (SPS) was shown to be extensive, such that only $10 \%$ and $13 \%$ of Cel7A and Cel7B, respectively, remained soluble after $6 \mathrm{~h}$ of incubation. Addition of PEG 4000 as an enzyme stabilizer reduced the adsorption of full length Cel7B, however only a weak positive effect could be observed for Cel7A. The impact of PEG on catalytic modulus varied greatly among these enzymes and as well as among of the full enzymes. For instance, a weak positive effect was observed on catalytic modulus of Cel7A, which had shown 32\% adsorption to biomass substrate. Interestingly for both full length enzymes, the addition of PEG completely eliminated the irreversible adsorption to lignin.

\subsection{Impact of Amphiphiles on Enzyme Structure}

The presence of an interaction between the micelles or monomers of amphiphiles (surfactants and protein) and enzyme in a solution is undeniable. The primarily role of hydrophobic forces in the interaction of amphiphilic compounds (other than lipids) with "native" proteins from a variety of sources has been well substantiated [69]. As a result of the isothermal titration micro-calorimetry analysis of interaction between SDS and Casein, Liu et al. [70] found that when $\mathrm{NaCl}$ was applied to the complex, the enthalpy change corresponding to SDS binding to the casein chains was not 
significantly different than that in the absence of $\mathrm{NaCl}$, especially at low concentrations of SDS. This observation confirmed that the interaction of molecules of surfactants and the protein (e.g., enzyme) are mainly through the hydrophobic forces rather than electrostatic (Figure 3).

Figure 3. Schematic of interaction between protein molecules (e.g., enzyme) and non-ionic surfactants through hydrophobic interaction (Adopted from Maldonado-Valderramaa, and Rodríguez Patino, [71]).

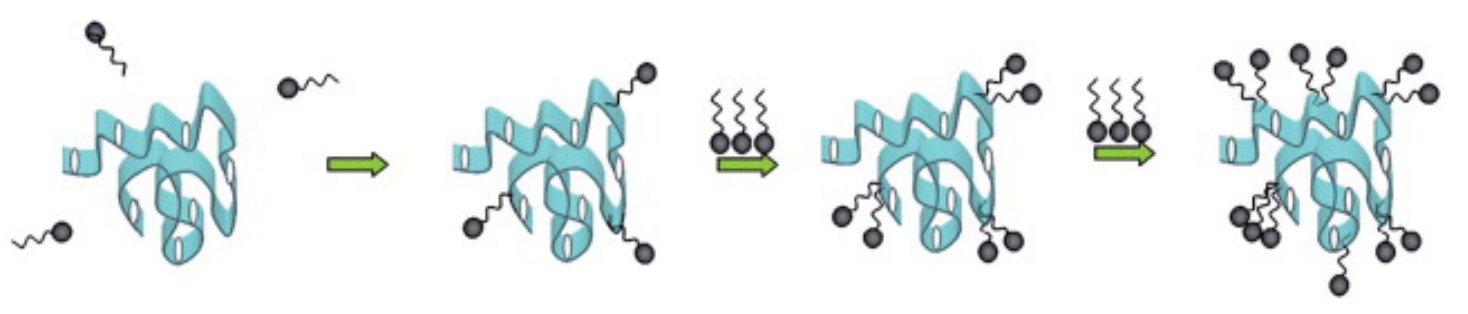

It was also reported that the amino acids of tyrosine (Tyr), tryptophan (Trp), glutamic acid (Glu), and aspartic acid (Asp), which are exposed to the surface of cellualse, play an important role in cellulase binding to substrate and biodegradation of substrate [72]. Therefore Zhang et al. [73] hypothesized that the interaction of cellulase and PEG in solution is primarily originating from hydrophobic interactions that are formed between the aromatic rings of the so-called amino acids and the $-\mathrm{CH}_{2}-\mathrm{CH}_{2}$ group of the PEG 4000 in solution.

Regardless of whether surfactants are present as monomers at the surface of biomass [54] or as micelles in solution (at above CMC level), the enzyme structure is anticipated to be modified as a result of the contact with surfactants. Studies showed that it is the conformational changes of protein in the presence of poly-electrolitic micelles as well as monomers (obtained by disintegration with $0.7 \mathrm{M}$ salts) that affected the enzyme activity (e.g., lipase) [55]. In agreement with these results, it was found that the reason behind the reduction in xylanase activity during incubation with Standapol-A surfactants was due to denaturation of enzyme that was observed as reduction in ellipticity obtained from Circular dichroism analysis [22].

Conformational changes in enzyme due to interaction with surfactants seem to occur at different sub-structures of enzymes and to different extents. This observation should originate from a variety of factors that relating to surfactant properties (CMC, charge type and districusion, hydrophilic lipophilic balance (HLB) number, etc.), as confirmed by Rumi et al. [30]. It was reported that the rheological properties of the solution is modified based on the HLB of the surfactants, which itself modifies the secondary structure of the proteins present in the solution and significantly affects the enzyme activity [73]. According to Kramer theory, the viscosity of the solvent is responsible for a friction against protein in solution and results in decreased motion and inhibitory impact on catalysis in motile enzyme. Uribe et al. [74] found a direct correlation between viscosity ( $\eta$ ) and the inhibition of the maximum rate of enzyme catalysis $\left(V_{\max }\right)$.

It was reported that while increasing the concentration of Brij 35 and SDS induced $\alpha$-helix formation in a solution of lipoxygenase $\left(\operatorname{LOX}_{1}\right)$, Tween 20 increased the $\beta$-structure of the enzyme [19]. The extent and nature of the modifications imposed seemed to not be solely dependent to the charges of the surfactants, as two surfactants of Sodium deoxycholate (DOC) and SDS, with negative charges exhibited different effects on enzyme structure. Specifically, SDS increased both 
$\alpha$-helix and aperiodic structure at higher concentrations, whereas DOC increased $\alpha$-helix and decreased aperiodic structure of LOX1 [19]. Also, a study conducted by our group [43] showed that in hydrolysate of corn stover containing Triton X-100 and Tween-20, the $\alpha$-helix sub-structure of soluble proteins (including cellulase, $\beta$-glucosidase and potentially protein of biomass) was regenerated by $53.9 \%$ and $71.0 \%$, respectively, compared to the control condition at which the protein stabilizers were absent.

According to another study conducted by Zhang et al. [73], it was observed that the UV absorbance band of the mixed solution of CBH I-PEG 4000 at $276 \mathrm{~nm}$ gradually weakened with the increase of PEG 4000 concentration, due to disturbance and deformation of enzyme structure. The analysis of the second derivative of the peaks, which is better representative of the amino acid residues in protein, showed that when the concentration of PEG 4000 in the CBH I-PEG4000 mixture was $10 \mathrm{mg} / \mathrm{mL}$ and $20 \mathrm{mg} / \mathrm{mL}$, respectively, the bands at $274 \mathrm{~nm}$ disappeared.

\subsection{Prohibition in Thermal Deactivation}

According to Karr and Hotzapple, [53], surfactants such as Tween provide a thermal protection for cellulolytic enzymes during biomass hydrolysis. They found that the optimum temperature for enzymatic hydrolysis of biomass was $10{ }^{\circ} \mathrm{C}$ higher in the presence of Tween, than that for Tween-free samples. Kumar and Wyman, [26] also observed a pronounced effect of enzyme stabilizers (PEG, Twee and BSA) over an extended period of hydrolysis of corn stover (that was pretreated with different techniques). As a result Kumar and Wyman, [26], proposed that the surfactant probably reduces the enzyme deactivation by decreasing the impact of prolonged contact to air, heat and/or agitation. However, the role of surfactants in protection of enzyme from thermal deactivation was rejected by Badley et al. [74].

\section{Important Factors in Efficacy of Amphiphiles}

\subsection{Role of Lignin}

Lignin is known to reduce the efficiency of enzymatic hydrolysis for several reasons. (i) Lignin creates a shield for cellulose against of the physical, microbial or chemical degradation and restricts the significant swelling of the cell wall, thereby restricting accessibility of cellulose to the enzyme. This necessitates the escalation in enzyme utilization or extension in reaction times to achieve high conversions $[1,75,76]$. (ii) Lignin unproductively adsorbs a large fraction of the cellulase, making it unavailable for enzymatic hydrolysis of cellulose [77]. Evidence from flow through systems strongly suggests that the remnant lignin in solution during pretreatment with acid or water/steam reacted to form compounds with limited solubility that precipitated back on the surface of biomass [58,59]. As can be understood, elimination of lignin or alleviation of its negative impact on enzymatic reaction can be greatly beneficial in improvement of hydrolysis. Unfortunately, the pretreatment techniques developed thus far are not quite successful at sufficiently and economically eliminating the lignin. In addition, pretreatment techniques such as organosolve pretreatment tend to be too expensive to make the ethanol production from cellulosic biomass justifiable, therefore techniques that can isolate the lignin can be of great value for the biomass conversion process. 
Some studies have shown that amphiphiles such as surfactants (e.g., Tween 20, Tween 80, Triton-100, SDS, DoTAB) and protein-based biopolymers such as casein and BSA are more effective at improving the enzymatic hydrolysis yield of lignin containing substrate than pure cellulose $[1,27,36,42]$, while other studies demonstrated that these additives (enzyme stabilizers) are as effective on pure cellulose as they are on lignocellulosic materials [12,26]. It was observed that although the cellulase was adsorbed to pure cellulose significantly $[29,36]$, the concentration of cellualse started to increase in solution after $1 \mathrm{~h}$ [29], meaning that the adsorbed cellulose started to desorb from substrate after the hydrolysis reaction was completed. Although it is believed that lignin is the primary cause of enzyme deactivation, the negative impact of crystalline cellulose might also be present [29], as it was shown that the improvement in enzymatic hydrolysis yield was increased as the concentration of crystalline cellulose was decreased.

\subsection{Role of Amphiphiles Properties}

According to many studies, PEG competes with the protein of interest (enzyme) on adsorption to surfaces (e.g., biomass) [78]. Therefore, the higher the surface density and chain length of PEG, the more desirable the exclusion of protein will become. In agreement with Jeon et al. [78], Malmstrem et al. [79] pointed that polymer surface density is the major contributing feature for efficient protein adsorption resistance. The Increase in conversion rate from ethylene oxide $\left(\mathrm{EO}_{4}\right.$ to $\left.\mathrm{EO}_{6}\right)$ for an amphiphile enzyme stabilizer is in agreement with earlier findings that show longer E-O chains improve the enzymatic conversion yield up to $\mathrm{EO}_{80}$. The result of a study that investigated surfactants with $\mathrm{EO}$ groups, confirmed that the differences in hydrogen bonding properties is not the factor that influences the reaction yield, and it is in fact the role of hydrophobic interactions that has a determinative role.

Others have studied the role of surfactants as enzyme stabilizers in relation to their charge distributions and the associated impact on electrostatic interaction with the protein of interest. Many studies showed that non-ionic surfactants can affect the cellualse more positively compared to anionic surfactants [27,37]. Another study showed that the cationic surfactants are more effective in stabilizing cellulytic enzymes than anionic surfactants [34]. According to Rouimi et al. [30], even proteins such as whey and casein do not behave similarly when it comes to rheological properties of the liquid.

A contradictory result shows that the surfactants enhance the hydrolysis of cellulose regardless of their charges [32]. It is apparent that in addition to surfactant charges, there are other variables affecting the impact of additives on enzymes. A finding demonstrated that surfactants with the same charge can still affect the enzyme in different ways. For instance the two anionic surfactants of DOC and SDS, exhibited different effects on enzyme structure [23].

In agreement with Lu et al., 2002 that suggested the association between the modifications of enzyme structure and the rheological properties of the solution imposed by surfactants, Rouimi et al. [30] studied the rheological behavior of different proteins of casein and whey and compared them with surfactants. It was found that flexible and disordered macromolecules such as casein form film on the surfaces with a very low viscoelasticity, while globular proteins such as $\beta$-lactoglobulin, Lysozyme, and BSA form films with higher viscoeelasitity and lower rigidity [80]. It was proposed that the high viscoelasticity of globular proteins can be attributed to high packing density and strong intermolecular interactions (e.g., hydrogen bond, electrostatic and hydrolphobic interactions) compared to that of 
proteins with loose mobile structure such as casein [81]. It is known that proteins and low molecular weight surfactants have different behavior from each other as well. The difference in packing density and interfacial interaction of whey, casein and BSA proteins suggest that different levels of improvement would be observed if casein (low viscoelasticity) is used as an enzyme stabilizer compared with BSA or whey proteins (with higher viscoelasticity).

\subsection{Role of Amphiphiles Concentration}

In order for the amphiphiles to be economically viable in biomass conversion process, the quantity of the additive used should be minimized as much as possible. An important question is whether the application of amphiphiles beyond a certain concentration would be un-necessary in improving the hydrolysis reaction yield. Eckard et al. [36,37] found that at a fixed optimum temperature of $51{ }^{\circ} \mathrm{C}$, a relative increase of $7.0 \%$ (from $58.7 \%$ to $63.2 \%$ ) was achieved in glucose yield by increasing the PEG concentration up to $0.5 \mathrm{~g} / \mathrm{g}$ glucan when $14.2 \mathrm{mg} / \mathrm{g}$ glucan of Cellic ${ }^{\mathrm{TM}} \mathrm{Ctec}$ was applied. The increase in xylose yield was $5.1 \%$ (from $29.8 \%$ to $31.3 \%$ ), when the PEG concentration was increased up to $0.6 \mathrm{~g} / \mathrm{g}$ glucan. Similar to these results, Qi et al. [18] reported an increase in xylan conversion from dilute acid pretreated wheat straw, as the concentration of PEG was incrementally increased. According to Kurakake et al. [22], the activity of xylanase was improved slightly as the concentration of nonionic surfactants was increased, except when olinoor 1100 was used. In agreement with this Kaar and Holtzaple, [53] stated that a higher concentration of PEG was more effective at improving enzymatic hydrolysis.

Although the results of an study from Kumar and Wyman, [26] on AFEX, ARP, dilute acid, controlled $\mathrm{pH}$, and lime pretreated corn stover demonstrated that the increase of PEG concentration beyond $0.3 \mathrm{~g} / \mathrm{g}$ glucan did not have a significant effect on sugar yield, their study showed that higher PEG concentrations did result in significant increases in sugar yield for lime and $\mathrm{SO}_{2}$ pretreated CS. Perhaps the increase in concentration of surfactants is contributing to the increase of the hydrolysis yield by the increase in the unit number of surfactant micelles. This is because it was shown that at a concentration lower than $0.1 \mathrm{M}$, the increase in surfactant concentration was reported to impact only the micelle numbers [82]. It is important to note that according to Jacquilin et al. [83], it is not the increasing total concentration or the micellar concentration of amphiphils that result in an increase in the binding ratio (bovine serum albumin, chymotrypsinogen), but an increase in the equilibrium monomer concentration leads to a larger numbers of $\mathrm{g}$ SDS/g protein.

According to a model suggested by Viparelli et al. [84], the micelles act like micro carrier supports for the enzyme, which improve the catalytic reaction that occurs at the interface of the micelle-aqueous phase when compared to that of pure aqueous phase. In addition, increasing the concentration of surfactants up to a certain extent could have the effect of increasing the number of surfactants adsorbed to the hydrophobic surfaces of biomass that would otherwise cause an irreversible adsorption of proteins and deactivation.

\subsection{Role of Enzyme Loading}

According to several studies (reviewed here), the lower enzyme loadings are of specific benefits when amphiphiles are used as additives during hydrolysis of biomass. According to Larson et al. [85], 
at a high solid loading of saccharification (26\% for steam exploded spruce), when 0.01 (g DM) $)^{-1}$ PEG is used as an enzyme stabilizer, the absolute improved cellulose conversion is about $16 \%$ over a range of 2-6 FPU ( $(\mathrm{g} \mathrm{DM})^{-1}$ of enzyme used. However, at enzyme loadings of above 6 FPU, the improvement effect leveled off [85]. Authors reported that in regard to the severity of pretreatment technique used, application of $0.01(\mathrm{~g} \mathrm{DM})^{-1}$ PEG at high dry matter loadings $(\sim 26 \%), 24 \%-45 \%$ of enzyme can be saved. These finding were in agreement with those of Kumar et al. [26]. Perhaps application of a high concentration of enzyme can mask the improvement effect that would be obtained from the use of enzyme stabilizers by releasing a high concentration of sugar and leaving no room for improvement in enzymatic hydrolysis yield. In another study [42], it was found that the glucose and xylose yield was improved from $10 \%$ to $38.5 \%$ and from $3.1 \%$ to $26.7 \%$, respectively, when extrusion pretreated CS was hydrolyzed with the aid of casein using 25 FPU of cellulase. However, as the amount of the enzyme was increased to 37.5 and 50 FPU, no significant increase in sugar yield associated with the casein treatment was observed in most cases. This demonstrates the importance of using lower enzyme dosages when applying additives.

\subsection{Role of Temperature}

Additives such as PEG exhibit only a very small beneficial effect in biomass conversion when used at temperatures lower than $25^{\circ} \mathrm{C}$ [28]. Three hypotheses have been suggested in order to explain this observation. First, the aqueous solubility of PEG was reported to be unlimited for all degrees of polymerization at room temperature [66], which makes the interaction of PEG with hydrophobic sites of biomass (e.g., lignin) weak. According to Borjesson et al. [28], PEG (aqueous soluble polymer) demonstrates an inverse solubility, meaning that with an increase of temperature its solubility decreases, and as a result causes this polymer to form a stronger interaction with lignin. It was observed that the adsorption of PEG onto SPS (steam pretreated spruce) was increased by a factor of two as the temperature was increased from $20^{\circ} \mathrm{C}$ to $40{ }^{\circ} \mathrm{C}$ [28]. Studies conducted by Borjesson et al. [28] were in agreement with that of Eckard et al. [38], who showed that when the Tween concentration was held at $0.47 \mathrm{~g} / \mathrm{g}$ glucan (optimum concentration), and the incubation temperature of corn stover with surfactant was increased from $45{ }^{\circ} \mathrm{C}$ to $51{ }^{\circ} \mathrm{C}$, glucose yields was increased from $59.6 \%$ to $65.6 \%$. However, further increasing the temperature to above $51{ }^{\circ} \mathrm{C}$ did not result in an additional positive effect on glucose or xylose yields [38]. Tirosh et al. [86] found that the number of water molecules bound per chain of PEG 2000 was $136 \pm 4$ in the free-state and $210 \pm 6$ while attached over micelles. This corresponds to 3.1 to 4.8 water molecules per monomer unit, respectively. The high solubility of PEG in water (determined experimentally) along with its high $\mathrm{A}_{2}$ [second viral coefficient or excluded volume (v)] and relationship with molecules of water and rapid motion of PEG chains in aqueous medium [being a highly flexible chain with steric factor $(\sigma)$ of $\sim 1$ ] suggest that PEG exists in water as a highly hydrated polymer with a large excluded volume $[65,87]$.

The second hypothesis to explain the effect of temperature on surfactants relates to the fact that PEG conformation is altered by temperature. For example, it was found that PEG experiences contraction and dehydration as temperature rises. This facilitates an enhanced packing density on adsorbed surfaces that enhances the steric repulsion. There are many models or theories that have been developed to describe the parameters that affect the resistance of a polymer-coated surface to 
non-specific protein adsorption. One of these models, depicted in Figure 2, predicts that each individual polymer chain exist as a mushroom or half sphere (based on the concentration) [88] adsorbed to the surface, that upon compression is squeezed out from the beneath the protein of interest [63]. Studies have shown that these proteins can be desorbed from PEG, based on the conformational changes adopted by this polymer. For instance, the helical or amorphous conformation of PEG was found to be protein resistant whereas the "all-trans" conformation was not [89].

Finally, the third hypothesis explaining the increased effectiveness of surfactant-treated systems with increased temperature relates to reduced viscosity. In contrast to the polymer-surfactant system, that retains high viscosity at elevated temperature; solutions containing surfactants or proteins demonstrated a reduced viscosity as the temperature rises [30,90]. According to Kramer theory, the viscosity of the solvent is responsible for a friction against protein in solution and results in decreased motion and inhibitory impact on catalysis in motile enzyme [74]. It has been reported that at a low ionic strength $(0.003-0.01 \mathrm{M})$ and neutral or alkaline $\mathrm{pH}$ and low temperatures $\left(4^{\circ} \mathrm{C}\right), \alpha$ and $\beta$-casein occur as monomers. However, as ionic strength and/or temperature were increased, both $\alpha$ and $\beta$ caseins self-associated to dimer, tetramer, hexamer and other polymers up to 20-60 subunits (CMC: $0.3-0.7 \mathrm{mg} / \mathrm{mL}$ ) [91]. Therefore, an additional hypothesis can be suggested that higher temperatures increase the formation and concentration of biopolymers and micelles formed by casein polypeptides, and resultantly increase the ratio of reactions occurring under the improved condition (e.g., at the interface of micelles aqueous phase) [84].

\subsection{Role of Time}

Role of incubation period of amphiphiles with biomass is an important factor in determining the efficiency of enzymatic hydrolysis. As a result of the recent investigation on this subject, Zhang et al. [73] showed that without PEG 4000 the irreversible adsorption of CBH I to corn stover was about $85 \%$ of added enzyme. However, as the time interval of the incubation of corn stover with PEG 4000 was increased from $0.5 \mathrm{~h}$ to $1 \mathrm{~h}$ and $2 \mathrm{~h}$, the adsorption of $\mathrm{CBH}$ I was reduced to $73.75 \%$, $69.37 \%$ and $67.22 \%$, respectively. According to this author, as the incubation period increased up to $2 \mathrm{~h}$, the PEG was twisted and whorled further into the lignin which helped to the CBHI desorption by enhancing the hydration shell around the biomass (specially lignin), which generated a higher steric repulsion impact on enzymes.

Cellulolytic enzymes would otherwise be irreversibly adsorbed by non-productive sites and be deactivated. As a result, the glucose yield was increased by $8.1 \%$, when the incubation interval was raised from $0.5 \mathrm{~h}$ to $1 \mathrm{~h}$. However, a significant increase was not observed when further extension in incubation up to $2 \mathrm{~h}$ was conducted [73]. According to a systematic study conducted by Eckard et al. [36] to understand the role of incubation time of PEG or Tween 20 with high lignin containing corn stover prior to hydrolysis, time $(1-5 \mathrm{~h})$ was not found to be a significant factor. Perhaps further research in this topic can help elucidate the role of this factor.

It was also proposed that the impacts of enzyme stabilizers are improved to a higher extent as the hydrolysis reaction progressed up to $72 \mathrm{~h}$. According to Kumar and Wyman, [26] at a cellulase and $\beta$-glucosidase level of 16.1 and $6.2 \mathrm{mg} / \mathrm{g}$ glucan, extending the hydrolysis from $24 \mathrm{~h}$ to $72 \mathrm{~h}$ for Avicel increased the sugar yield from $14 \%-19 \%$ to $\sim 30 \%$ when $0.3-0.6 \mathrm{~g} / \mathrm{g}$ glucan of enzyme stabilizer 
(e.g., BSA, Tween 20, PEG 6000) was used. It is possible that amphiphiles protect cellulolytic enzyme from the higher inactivation by the increased thermal and shear forces associated with extended hydrolysis time.

\subsection{Role of Order of Addition}

According to Kurakake et al. [22], the order of addition of surfactants to substrates can either inhibit or accelerate the enzymatic hydrolysis. It was found that application of surfactants to buffer and filter paper (substrate) first, followed by addition of enzyme is more effective in improving the sugar yield compared to when enzyme is simultaneously incubated with surfactants and feed stock. Zheng et al. [29] tested the order of addition of Tween 20 as an enzyme stabilizer for hydrolysis of creeping wild Rygrass. It was found that addition of Tween 20 to biomass solution prior to addition of enzyme resulted in a much higher amount of free protein and increased enzyme activity compared to when the surfactants were added to the solution after the enzyme. From these results it was suggested that although surfactants can prevent from enzyme irreversible adsorption to non-active sites, they cannot replace the enzyme after have been adsorbed to biomass.

\subsection{Role of Mixed Micelles and Polymeric Micelles}

It was shown that the mixture of a non-ionic surfactant and Sodium dodecyl sulfate (SDS) (negatively charged) can form mixed micelles [92,93]. Protein partitioning in separation systems that contained these mixed micelles were shown to provide an effective combination for preservation of enzyme activity [94], e.g., polyoxyethylene surfactants $\left(\mathrm{C}_{12} \mathrm{EO}_{5}\right)$ and SDS. Errikson et al. [27] later showed that the hydrolysis of biomass in an Argimol-treated system was positively improved when a low quantity of SDS was mixed with Argimol. This author hypothesized that the formation of the mixed micelles of non-ionic surfactants and SDS will dilute the negative impact of the free SDS in solution. SDS was shown to reduce the irreversible adsorption of Ce7A to a higher extent than any other amphiphiles studied (Tween 20, Triton X-100, Triton X-114, DOTAB, Argimol) [27]. SDS is most prevalently known as a protein unfolding agent due to its application in the SDS-PAGE method. However, SDS has been reported to affect the refolding of protein [95] and decrease the loss of activity in enzymes [96]. Assistance in enzyme solubilization and reformation of protein secondary structure, specifically $\alpha$-helixes at specific concentrations $(>75 \mathrm{mM})$, were also reported as benefits of SDS [50].

Recently we used polymeric-micelles (PMs) of PEG-Tween 20, PEG-Brij 30, PEG-Triton X-100, and PEG-Casein for improvement of enzymatic hydrolysis in high $(\sim 20 \%)$ and low lignin $(\sim 7.2 \%)$ containing corn stover. According to Eckard et al. [52], the ethanol yield of separate saccharification and fermentation of a PMs-treated solution of pretreated corn stover was significantly improved compared to one treated with micelles only. Benefits of PMs might include improved interfacial properties such as increased solubilization of colloidal carriers [97], improved rheological properties of the solution [98] by reduction of surface tension of the solution (Figure 4) [99], and reduced hydrophobicity of reverse micelles (e.g., Triton) by ethylene oxide groups of polymers such as PEG [99] or lignocellulose [22]. It was found that these PMs were not effective for enzymatic hydrolysis of biomass lacking lignin or alkali pretreated corn stover (7.2\% lignin). The main reasons for the enhanced cellulase activity observed due to PMs of PEG-casein, PEG-Tween and PEG-Triton 
were found to be (in order of importance) the enhanced cellulase solubilization, reformation of $\alpha$-helix sub-structure and combination of induced cellulase solubilization, $\alpha$-helix reformation and chemical changes in micro-structure of biomass.

Figure 4. Schematic of potential structure of polymer-surfactant combination in solution and the resultant reduction in surface tension of the solution as a function of surfactant concentration (Adopted from Taylor and Penfold, [100]).

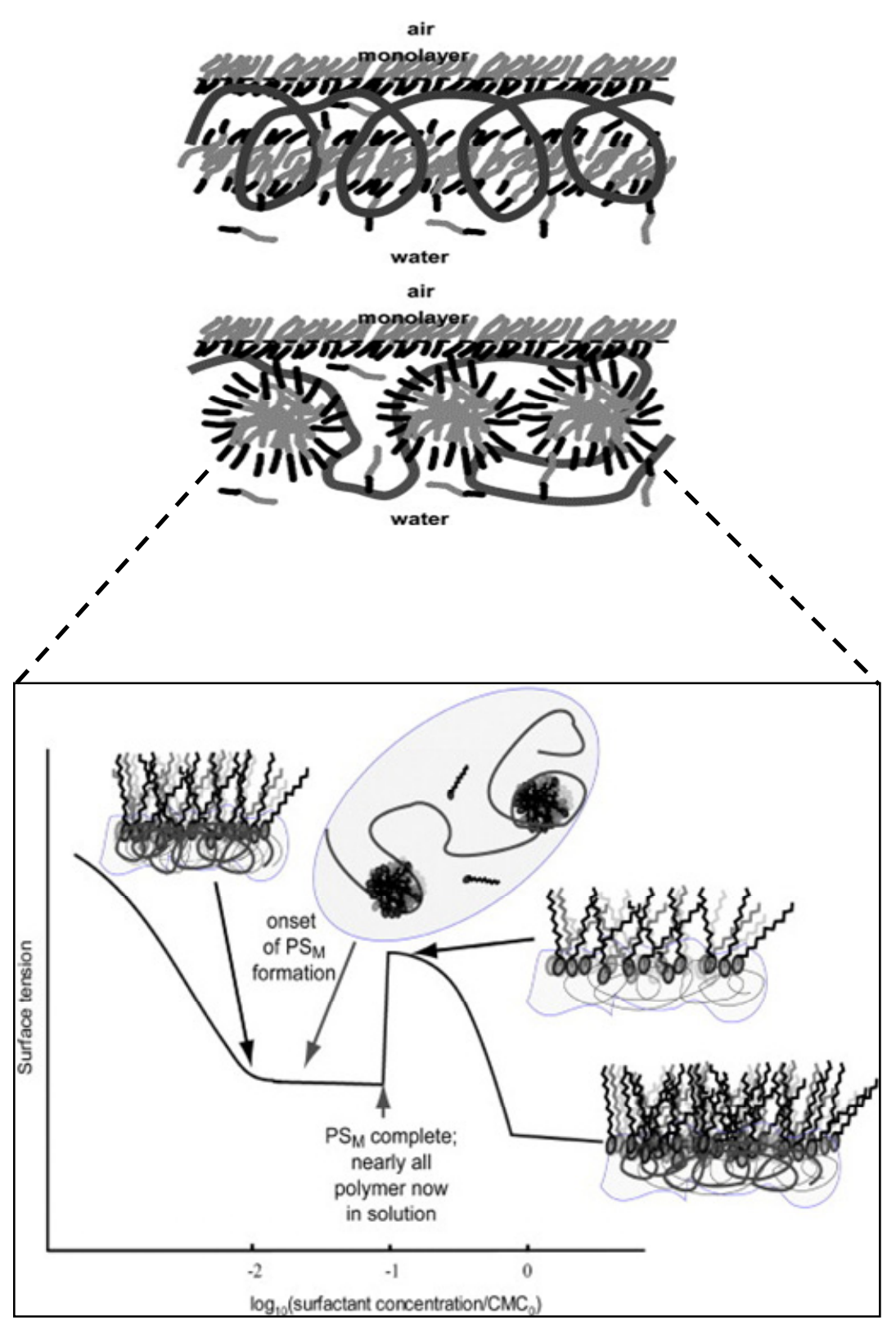

\section{Conclusions}

Despite of the intriguing process of converting agricultural residues and herbaceous grasses to fermentable sugars that can be converted to fuel grade ethanol, economical enzymatic hydrolysis of biomass remains a challenge. Utilizing a typical cellulase dose of $15 \mathrm{FPU} / \mathrm{g}$ glucan could account for about $32 \%$ of the produced ethanol cost (considering an enzyme cost of $\$ 10 / \mathrm{kg}$ and an ethanol price of $\$ 0.94 / \mathrm{L}$ ). Rapid inactivation of cellulolytic enzymes in biomass slurries is another challenge that 
demands the use of a higher amount of enzyme and prevents successful enzyme recycling. Amphiphiles such as surfactants (Tween, Brij, Triton, etc.) and proteins such as (BSA, Casein, soybean meal, corn steep liquor, etc.) are examples of additives with surface active properties that are utilized in hydrolysis and fermentation of biomass to prevent enzyme inactivation or modify the biomass when used during pretreatment. Surface active molecules can protect the protein of interest by reducing the surface tension and viscosity of solution and contact of enzyme with air-liquid interface. Amphiphiles prevent enzyme irreversible adsorption to non-specific sites such as lignin and crystalline cellulose that deactivate enzyme. They isolate and remove the hydrophobic degradation products released during biomass pretreatment, modify the chemical structure and surface hydrophobicity of biomass. As a result, a dramatic reduction in enzyme utilization can be expected when amphiphiles are used in biomass conversion process. In this manuscript, the efficacy, mechanism of action and important factors affecting the efficacy of amphiphiles on biomass hydrolysis was reviewed thoroughly to provide insights on efficient application of these molecules in biomass to ethanol conversion.

\section{References}

1. Yang, B.; Wyman, C.E. BSA treatment to enhance enzymatic hydrolysis of cellulose in lignin containing substrates. Biotechnol. Bioeng. 2006, 94, 611-617.

2. Ferreira, S.M.P.; Duarte, A.P.; Queiroz, J.A.; Domingues, F.C. Influence of buffer systems on Trichoderma reesei Rut C-30 morphology and cellulase production. Electron. J. Biotechnol. 2009, 12, 1-9.

3. Ma, A.Z.; Hu, Q.; Qu, Y.B.; Bai, Z.H.; Liu, W.F.; Zhuang, G.Q. The enzymatic hydrolysis rate of cellulose decrease with irreversible adsorption of cellobiohydrolase I. Enzym. Microb. Technol. 2008, 42, 543-547.

4. Himmel, M.E.; Ruth, M.F.; Wyman, C.E. Cellulase for commodity products from cellulosic biomass. Curr. Opin. Biotechnol. 1999, 10, 358-364.

5. Wingren, A.; Galbe, M.; Roslander, C.; Rudolf, A.; Zacch, G. Effect of reduction in yeast and enzyme concentrations in a simultaneous-saccharification-andfermentation-based bioethanol process. Technical and economic evaluation. Appl. Biochem. Biotechnol. 2005, 121, 485-499.

6. Wyman, C.E. What is (and is not) vital to advancing cellulosic ethanol. Trends Biotechnol. 2007, 25, 153-157.

7. Aden, A.; Foust, T. Technoeconomic analysis of the dilute sulfuric acid and enzymatic hydrolysis process for the conversion of corn stover to ethanol. Cellulose 2009, 16, 535-545.

8. Lynd, L.R.; Laser, M.S.; Bransby, D.; Dale, B.E.; Davison, B.; Hamilton, R.; Himmel, M.; Keller, M.; McMillan, J.D.; Sheehan, J.; Wyman, C.E. How biotech can transform biofuels. Nat. Biotech. 2008, 26, 169-172.

9. Dutta, A.; Dowe, N.; Ibsen, K.N.; Schell, D.J.; Aden, A. An economic comparison of different fermentation configurations to convert corn stover to ethanol using Z. mobilis and Saccharomyces. Biotechnol. Prog. 2010, 26, 64-72.

10. Klein-Marcuschamer, D.; Oleskowicz-Popiel, P.; Simmons, B.A.; Blanch, H.W. The challenge of enzyme cost in the production of lignocellulosic biofuels. Biotechnol. Bioeng. 2011, doi:10.1002/bit.24370. 
11. Kazi, F.K.; Fortman, J.A.; Anexm, R.P.; Hsum, D.D.; Adenm, A.; Duttam, A.; Kothandaraman, G. Techno-economic comparison of process technologies for biochemical ethanol production from corn stover. Fuel 2010, 89, S20-S28.

12. Li, J.; Li, S.-Z.; Fan, C.-Y.; Yan, Z.-P. The mechanism of polyethylene glycol (PEG) 4000 effect on enzymatic hydrolysis of lignocellulose. Colloid Surf. B 2011, 89, 203-120.

13. Yang, J.; Zhang, X.P.; Yong, Q.; Yu, S.Y. Three-stage hydrolysis to enhance enzymatic saccharification of steam-exploded corn stover. Bioresour. Technol. 2010, 13, 4930-4935.

14. Sathitsuksanoh, N.; Zhu, Z.; Zhang, Y.-H.P. Cellulose solvent- and organic solvent-based lignocellulose fractionation enabled efficient sugar release from a variety of lignocellulosic feedstocks. Bioresour. Technol. 2012, 117, 228-233.

15. Qiu, Z.; Aita, G.M.; Walker, M.S. Effect of ionic liquid pretreatment on the chemical composition, structure and enzymatic hydrolysis of energy cane bagasse. Bioresour. Technol 2012, 117, 251-256.

16. Holtzapple, M.; Cognata, M.; Shu, Y.; Hendrickson, C. Inhibition of Trichoderma reesei cellulase by sugars and solvents. Biotechnol. Bioeng. 1990, 36, 275-287.

17. Xiao, Z.Z.; Zhang, X.; Gregg, D.J.; Saddler, J.N. Effects of sugar inhibition on cellulases and beta-glucosidase during enzymatic hydrolysis of softwood substrates. Appl. Biochem. Biotechnol. 2004, 113, 1115-1126.

18. Qing, Q.; Yang, B.; Wyman, C.E. Xylooligomers are strong inhibitors of cellulose hydrolysis by enzymes. Bioresour. Technol. 2010, 101, 9624-9630.

19. Kim, T.H.; Lee, Y.Y.; Sunwoo, C.; Kim, J.S. Pretreatment of corn stover by low liquid ammonia recycle percolation process. Appl. Biochem. Biotechnol. 2006, 133, 41-57.

20. Zhu, Y.M.; Kim, T.H.; Lee, Y.Y.; Chen, R.G.; Elander, R.T. Enzymatic production of xylooligosaccharides from corn stover and corn cobs treated with aqueous ammonia. Appl. Biochem. Biotechnol. 2006, 130, 586-598.

21. Ximenes, E.; Kim, Y.; Mosier, N.; Dien, B.; Ladisch, M. Deactivation of cellulases by phenols. Enzym. Microb. Technol. 2011, 48, 54-60.

22. Kurakake, M.; Ooshima, H.; Kato, J.; Harano, Y. Pretreatment of bagass by non-ionic surfactant for the enzymatic hydrolysis. Bioresour. Technol. 1994, 49, 247-251.

23. Sonati, S.; Appu, R.A.G. Kinetic and structural studies on the interaction of surfactants with lipoxygenase L1 from soybeans (glycine max). J. Agric. Food Chem. 1993, 41, 366-371.

24. Hayashi, Y.; Talukder, M.M.R.; Wu, J.; Takeyama, T.; Kawanishi, T.; Shimizu, N.J. Increased activity of Chromobacterium viscosum lipase in AOT reverse micelles in the presence of short chain methoxypolyethylene glycol. J. Chem. Technol. Biotechnol. 2001, 76, 844-850.

25. Talunder, M.M.; Takayama, T.; Hayashi, Y.; Wu, J.C.; Kawanishi, T.; Shimizu, N.; Ogino, C. Improvement of enzyme activity and stability by adding of low molecular weight polyethylene glycol to sodium bis(2-ethyl-L-hexyl) sulfosuccinate/ isooctane reverse micelles. Appl. Biochem. Biotechnol. 2003, 110, 101-111.

26. Kumar, R.; Wyman, C.E. Effect of additives on the digestibility of corn stover solid following pretreatment by leading technologies. Biotechnol. Bioeng. 2008, 102, 1544-1557.

27. Erriksson, T.; Karlsson, J.; Tjerland, F. Mechanism of surfactant effect in enzymatic hydrolysis of lignocellulose. Enzym. Microb. Technol. 2002, 3, 353-364. 
28. Borjesson, J.; Engqvist, M.; Slipos, B.; Tjerneld, F. Effect of polyethylene glycol on enzymatic hydrolysis and adsorption of cellulose enzymes to pretreated lignocellulose. Enzym. Microb. Technol. 2007, 41, 186-195.

29. Zheng, Y.; Pan, Z.; Zhang, R.; Wang, D.; Jenkins, B. Non-ionic surfactants and non-catalytic protein. Treatment on enzymatic hydrolysis of pretreated creeping wild ryegrass. Appl. Biochem. Biotechnol. 2008, 146, 231-248.

30. Rouimi, S.; Schorsch, C.; Valenitini, C.; Vaslin, S. Foam stability and interfacial properties of milk protein-surfactnt systems. Food Hydrocll. 2005, 19, 467-478.

31. Tu, M.; Chandra, R.P.; Sadller, J.N. Recycling cellulase during the hydrolysis of steam exploded and ethanol pretreated lodgepole pine. Biotechnol. Prog. 2007, 65, 1130-1137.

32. Helle, S.S.; Duff, S.J.B.; Copper, D.G. Effect of surfactants on cellulose hydrolysis. Biotech. Bioeng. 1993, 42, 611-617.

33. Castanon, M.; Wilke, C.R. Effect of the surfactant Tween 80 on enzymatic hydrolysis of newspaper. Biotechnol. Bioeng. 1981, 23, 1365-1372.

34. Oshima, H.; Kurakake, M.; Kato, J.; Harano, Y. Enzymatic activity of cellulase adsorbed on cellulose and its change during hydrolysis. Appl. Biochem. Biotechnol. 1991, 31, 253-266.

35. Yang, B.; Wyman, C.E. Lignin Blockers and Uses Thereafter. U.S. Patent 7875444, 25 January 2011.

36. Eckard, A.D.; Muthukumarappan, K.; Gibbons, W. Pretreatment of extruded corn stover with polyethylene glycol to enhance enzymatic hydrolysis: Optimization, kinetics, and mechanism of action. BioEnergy Res. 2011, 5, 424-438.

37. Eckard, A.D.; Muthukumarappan, K.; Gibbons, W. Modeling of pretreatment condition of extrusion pretreated prairie cordgrass and corn stover with polyoxyethylen (20) sorbitan monolaurate. Appl. Biochem. Biotechnol. 2012, 167, 377-393.

38. Ballstros, J.; Olivia, M.; Carascoa, J. Simultaneous Saccharification and Fermentation of Steam-Exploded Poplar Biomass to Ethanol. Appl. Biochem. Biotechnol. 1998, 70-72, 369-381.

39. Alkasrawi, M.; Eriksson, T.; Börjesson, T.; Wingren, A.; Galbe, M.; Tjerneld, F.; Zacchi, G. The effect of Tween-20 on simultaneous saccharification and fermentation of softwood to ethanol. Enzym. Microb. Technol. 2003, 33, 71-78.

40. Wu, J.; Ju, L.K. Enhancing enzymatic saccharification of waste newsprint by surfactant addition. Biotechnol. Prog. 1998, 14, 649-652.

41. Yang, B.; Lebanon, W.; Wyman, C.E. Non-Catalytic Additives to Enhance Biodegradation of Cellulosic Biomass. U.S. Patent Provisional Application filed, case No. 2009-640-1, 22 April 2009.

42. Eckard, A.D.; Muthukumarappan, K.; Gibbons, W. Enhanced bioethanol production from pretreated corn stover via multi-positive effect of casein micelles. Bioresour. Technol. 2012, doi:10.1016/j.biortech.2012.07.100.

43. Eckard, A.D.; Muthukumarappan, K.; Gibbons, W. Evaluation of the role of polymerized micelles on yield of hydrolysis, chemical changes of biomass and cellulase structure and adsorption. Bioenergy Res. 2013, in press.

44. Yang, B.; Deidre, M.W.; Charles, E.W. Changes in the enzymatic hydrolysis rate of Avicel cellulose with conversion. Biotechnol. Bioeng. 2006, 94, 1122-1128.

45. Huyan, J.K.; Sung, B.K.; Chang, J.K. The effect of nonionic surfactants on the pretreatment and enzymatic hydrolysis of recycled newspaper. Biotechnol. Bioprocess Eng. 2007, 12, 147-151. 
46. Tu, M.; Zhang, X.; Piace, M.; McFarlance, P.; Saddler, N. Effect of surfactants on separate hydrolysis fermentation and simultaneous saccharification fermentation of pretreated lodgepole pine. Biotechnol. Prog. 2009, 25, 1122-1129.

47. Taherzadeh, M.J.; Keikhosro, K. Enzyme-based hydrolysis proceses for ethanol from lignocellulosic material, a review. BioResources 2007, 2, 707-738.

48. Parke, J.W.; Takahata, Y.; Kajuchi, T.; Akehata, T. Effects of non-ionic surfactant on enzymatic hydrolysis of used newspaper. Biotechnol. Bioeng. 1992, 39, 117-120.

49. Sinitsyn, A.P.; Mitkevich, O.V.; Klesov, A.A. Inactivation of cellulolytic enzymes by stirring and their stabilization by cellulose. Prikladnaya Biokhimiya i Mikrobiologiya 1986, 22, 759-765.

50. Palmqvist, E.; Hahn-Hagerdel, B.; Galbe, M.; Zacchi, G. The effect of water-soluble inhibitors from steam-pretreated willow on enzymatic hydrolysis and ethanol fermentation. Enzym. Microb. Technol. 1996, 19, 470-476.

51. Xue, Y.; Jameel, H.; Park, S. Strategies to recycle enzyme and their impact on hydrolysis for bioethanol production. Bioresources 2012, 7, 602-615.

52. Eckard, A.D.; Muthukumarappan, K.; Gibbons, W. Enzyme recycling in a simultaneous \& separate saccharification and fermentation of corn stover: Comparing polymeric micelles of surfactants and polypeptides. Bioresour. Technol. 2013, 132, 202-209.

53. Kaar, W.K.; Holtzapple, M.T. Benefits from Tween during enzymatic hydrolysis of corn stover. Biotechnol. Bioeng. 1998, 59, 419-427.

54. Seo, D.J.; Fujito, H.; Sakoda, A. Effects of a non-ionic surfactant, Tween 20, on adsorption /desorption of saccharification enzymes onto/from lignocelluloses and saccharification rate. Adsorption 2011, 17, 813-822.

55. Lindhoud, S. Polyelectrolyte Complex Micelles as Wrapping for Enzymes. Ph.D. Thesis, Wageningen Universiteit, Wageningen, The Netherlands, September 2009.

56. Kim, M.H.; Lee, S.B.; Ryu, D.D.Y. Surface deactivation of cellulose and its prevention. Enzym. Microb. Technol. 1982, 4, 99-103.

57. Biasutti, M.A.; Abuin, E.B.; Silber, J.J.; Correa, N.M.; Lissi, E.A. Kinetics of reactions catalyzed by enzymes in solutions of surfactants. Adv. Colloid Interface Sci. 2008, 136, 1-24.

58. Liu, C.; Wyman, C.E. The effect of flow rate of compressed hot water on xylan, lignin, and total mass removal from corn stover. Ind. Eng. Chem. Res. 2003, 42, 5409-5416.

59. Yang, B.; Wyman, C.E. Effect of xylan and lignin removal by batch and flowthrough pretreatment on the enzymatic digestibility of corn stover cellulose. Biotechnol. Bioeng. 2004, 86, 88-95.

60. Donohoe, B.S.; Decker, S.R.; Tucker, M.; Himmel, M.E.; Vinzant, T.B. Visualizing lignin coalescence and migration through maize cell walls following thermochemical pretreatment. Biotechnol. Bioeng. 2008, 101, 913-925.

61. Penner, M.H. Expression and measurement of enzyme activity. Curr. Protocol. Food Anal. Chem. 2001, doi:10.1002/0471142913.fac0101s00.

62. Allen, C.; Dos Santos, C.N.; Johnstone, S.A.; Gallagher, R.; Janoff, A.S.; Chiu, G.N.C.; Mayer, L.D.; Shu, Y.; Webb, M.S.; Li, W.M.; Bally1, M.B. Controlling the physical behavior and biological performance of liposome formulations through use of surface grafted poly(ethylene glycol). Biosci. Rep. 2002, 22, 225-249. 
63. Steels, B.M.; Leermakers, F.A.M.; Haynes, C.A. Analysis of compression of polymer mushrooms using self-consistent field theory. J. Chroma. B 2000, 743, 31-40.

64. Pribowo, A.; Arantes, V.; Saddler, J.N. The adsorption and enzyme activity profiles of specific Trichoderma reesei cellulase/xylanase components when hydrolyzing steam pretreated corn stover. Enzym. Microb. Technol. 2012, 50, 193-205.

65. Chen, N.; Fan, J.B.; Xiang, J.; Chen, J.; Liang, Y. Enzymatic hydrolysis of microcrystalline cellulose in reverse micelles. 2007, 1764, 1029-1035.

66. Lee, J.H.; Lee, H.B.; Andrade, J.D. Blood compatibility of polyethylene oxide surfaces. Prog. Polym. Sci. 1995, 20, 1043-1079.

67. Deshpande, M.V.; Eriksson, K.E.; Pettersson, L.G. An assay for selective determination of Exo-1,4,-Beta-glucanases in a mixture of cellulolytic enzymes. Anal. Biochem. 1984, 2, 481-487.

68. Kim, D.W.; Jang, Y.H.; Jeong, Y.K.; Son, K.H. Effect of a nonionic surfactant on the adsorption and kinetic mechanism for the hydrolysis of microcrystalline cellulose by endoglucanase I and exoglucanase II. Bull. Korean Chem. Soc. 1997, 18, 300-305.

69. Steinhardt, J.; Reynolds, J.A. Multiple Equilibria in Proteins; Academic Press: New York, NY, USA, 1970.

70. Liu, Y.; Guo, R. Interaction between casein and sodium dodecyl sulfate. J. Colloid Interface Sci. 2007, 315, 685-692.

71. Maldonado-Valderrama, J.; Rodríguez Patino, M. Interfacial rheology of protein-surfactant mixtures. Curr. Opin. Colloid Interface Sci. 2010, 15, 271-282.

72. Divne, C.; Stahlberg, J.; Teeri, T.T. High-resolution crystal structures reveal how a cellulose chain is bound in the 50A long tunnel of Cellobiohydrolase I from Trichoderma reesei. J. Mol. Biol. 1998, 275, 309-325.

73. Zhang, Y.; Zhang, Y.; Tang, L. Effect of PEG 4000 on cellulose catalysis in the lignocellulose saccharification process. J. Chem. Technol. Biotechnol. 2010, 86, 115-120.

74. Badley, R.A.; Carruthers, L.; Phillips, M.C. Hydrophobic free energy and the denaturation of proteins. Biochem. Biophys. Acta. 1997, 495, 110-113.

75. Lu, Y.; Yang, B.; Gregg, D.; Saddler, J.N.; Mansfield, S.D. Cellulase adsorption and an evaluation of enzyme recycle during hydrolysis of steam-exploded softwood residues. Appl. Biochem. Biotechnol. 2002, 100, 641-654.

76. Sutcliffe, R.; Saddler, J.N. The role of lignin in the adsorption of cellulases during enzymatic treatment of lignocellulosic material. Biotechnol. Bioeng. 1986, 17, 749-762.

77. Uribe, S.; Sampedro, J.G. Measuring solution viscosity and its effect on enzyme activity. Biol. Proced. Online 2003, 5, 108-115.

78. Jeon, S.I.; Andrade, J.D. Protein surface interactions in the presence of poly(ethylene oxide) ${ }_{2}$. Effects of protein size. J. Colloid Interface Sci. 1991, 142, 159-166.

79. Malmstren, M.; VanAlstine, J.M. Adsorption of poly (ethylene glycol) amphiphiles to form coatings which inhibit protein adsorption. J. Colloid Interface Sci. 1996, 177, 502-512.

80. Graham, D.E.; Phillips, M.C. Proteins at liquid interfaces. V. Shear properties. J. Colloid Interface Sci. 1980, 76, 240-250.

81. Dickinson, E. Adsorbed protein layers at fluid interfaces: Interactions, structure and surface rheology. Colloids Surf. B 1999, 15, 161-176. 
82. Karlstrom, G. A new model for upper and lower critical solution temperature in poly ethylene oxide solusions. J. Phys. Chem. 1985, 89, 4962-4964.

83. Jacquilin, A.; Tnford, R.; Tanford, C. Binding of dodecyl sulfate to proteins at high binding ratios. Possible implications for the state of proteins in biological membranes. Proc. Natl. Acad. Sci. USA 1970, 66, 1002-1006.

84. Viparelli, P.; Alfani, F.; Cantarella, M. Models for enzyme superactivity in aqueous solutions of surfactants. Biochem. J. 1999, 344, 765-73.

85. Larsen, J.; Henning, J. Methods for Reducing Enzyme Consumption in Second Generation Bioethanol Fermentation in the Presence of Lignin. WO Patent WO/2009/095781, 8 June 2009.

86. Tirosh, O.; Barenholz, Y.; Katzhender, J.; Priev, A. Hydration of polyethylene glycol-grafted liposomes. Biophys. J. 1998, 74, 1371-1379.

87. Lang, M.C.; Laupretre, F.; Noel, C.; Monnerie, L. Molecular motion of polyethylene oxide in dilute solutions studied by electron spin resonance and nuclear magnetic resonance. J. Chem. Soc. Faraday Trans. II 1979, 75, 349-355.

88. De Gennes, P.G. Conformation of polymers attached to an interface. Macromolecules 1980, 13, 1069-1075.

89. Harder, P.; Grunze, M.; Dahint, R.; Whitesides, G.M.; Laibinis, P.E. Molecular confor- mation in oligo(ethylene glycol)-terminated self-assembled monolayers on gold and silver surfaces determines their ability to resist protein adsorption. J. Phys. Chem. B 1998, 102, 426-436.

90. Shashkina, J.A.; Philippova, O.E.; Zaroslov, Y.D.; Khokhlov, A.R.; Pryakhina, T.A.; Blagodatskikh, I.V. Rheology of viscoelastic solutions of cationic surfactant. Effect of added associating polymer. Langmuir 2005, 21, 1524-1530.

91. Harjinder, S.; Flanagan, J. Milk Proteins. In Handbook of Food Science, Technology and Engineering; Hui, W.H., Ed.; Taylor \& Francis: New York, NY, USA, 2006.

92. Jonstromer, M.; Strey, R. Non-ionic bilayers in dilution solutions-effect of additives. J. Phys. Chem. 1992, 96, 5993-6000.

93. Schomaker, R.; Strey, R. Effect of ionic surfactants on non-ionic bilayers-bending elasticity of weakly charged membrane. J. Phys. Chem. 1994, 98, 3908-3912.

94. Sivars, U.; BergfeltK, P.L.; Tjerland, F. Protein partitioning in weakly charged polymer-surfactant aqueous two-phase system. J. Chromatogr. B 1996, 680, 43-53.

95. Naem, A.; Khan, R.H. Characterization of molten globule state of cytochrome c at alkaline, native and acidic $\mathrm{pH}$ induced by butanol and SDS. Int. J. Biochem. Cell Biol. 2004, 36, 2281-2292.

96. Moore, B.M.; Flurkey, W.H. Sodium dodecyl sulfate activation of a plant polyphenoloxidase. J. Biol. Chem. 1990, 265, 4982-4988.

97. Ahl, P.L.; Bhatia, S.K.; Meers, P.; Roberts, P.; Stevens, R.; Dause, R.; Perkins, W.R.; Janoff, A.S. Enhancement of the in vivo circulation lifetime of L- $\alpha$ line liposomes: Importance of liposomal aggregation versus complement opsonization. Biophys. Acta. 1997, 1329, 370-382.

98. Lu, K.W.; Pérez-Gil, J.; Taeusch, H.W. Kinematic viscosity of therapeutic pulmonary surfactants with added polymers. Biochim. Biophys. Acta 2009, 1788, 632-637. 
99. Yamada, Y.; Kuboi, R.; Komasawa, I. Increased activity of Chromobacterium viscosum lipase in aerosol OT reverse micelles in the presence of nonionic surfactants. Biotechnol. Prog. 1993, 9 , 468-472.

100. Taylor, D.J.F.; Penfold, R.K.T. Polymer/surfactant interactions at the air/water interface. Adv. Colloid Interface Sci. 2007, 132, 69-110.

(C) 2013 by the authors; licensee MDPI, Basel, Switzerland. This article is an open access article distributed under the terms and conditions of the Creative Commons Attribution license (http://creativecommons.org/licenses/by/3.0/). 